\title{
FOXM1 Gene
}

National Cancer Institute

\section{Source}

National Cancer Institute. FOXM1 Gene. NCI Thesaurus. Code C101580.

This gene is involved in both transcriptional regulation and cell division. 